\title{
Characterisation of HER Heterodimers in Breast Cancer Using in situ
}

\section{Proximity Ligation Assay}

Fabrício FT Barros ${ }^{1}$, Tarek MA Abdel-Fatah², Paul Moseley², Christopher C Nolan", Alice C Durham¹, Emad A Rakha1,3, Stephen Chan², Ian O Ellis1,3, Andrew R Green ${ }^{1}$

1Molecular Pathology Research Unit, Division of Oncology, School of Medicine,

University of Nottingham, Nottingham City Hospital, Nottingham, NG5 1PB

${ }^{2}$ Clinical Oncology, ${ }^{3}$ Department of Histopathology, Nottingham University Hospitals

NHS Trust, City Hospital Campus, Nottingham, NG5 1PB, UK.

Corresponding Author: Andrew R Green (andrew.green@nottingham.ac.uk). Tel: +44 (0) 1158231407 Fax: +44 (0) 1159627768 


\section{Abstract}

Introduction: HER2 plays an important role in breast cancer progression and provides predictive and prognostic information. HER2 receptor family members function through dimerisation, which can lead to impact on cell function, growth and differentiation; however their value in breast cancer development remains to be defined. This study aims to examine the relationships of HER2 heterodimers to breast cancer characteristics in trastuzumab naïve and treated cases.

Methods: HER2 protein (IHC), HER2 gene (chromogenic ISH) and HER2 heterodimerisation status (chromogenic in situ proximity ligation assay; PLA) was assessed in two breast cancer series prepared in tissue microarray (TMA) format.

\section{Results:}

A range of signals/cell for each HER2 heterodimer was detected ( $0-34.6$ signals/ cell). The vast majority of cases with HER2 heterodimers showed HER2 gene amplification and/or protein expression. There was an association between HER2 dimerisation with HER3 and HER4 and their protein expression level but no such association was found in with HER1 (EGFR). Of the HER2+ cases, 74\%, 66\% and $58 \%$ showed heterodimers with EGFR, HER3 and HER4 respectively. $51 \%$ of HER2+ tumours expressed all three heterodimers whereas $23 \%$ of the cases did not show expression of any of the three heterodimers. There was an inverse association between the presence and levels of HER2 heterodimers and hormone receptor expression in HER2+ tumours. Tumours exhibiting high levels of HER2 heterodimers demonstrated aggressive clinicopathological features and poor outcome. In the HER2 + cases, dimerisation with EGFR and HER3 but not with HER4 showed an association with aggressive features. There was no association between HER2 heterodimers with patient breast cancer specific survival or recurrence in HER2+ breast cancer in those patients receiving trastuzumab or not. 
Conclusions: Our results demonstrate that HER2 dimerisation is a complex process that may underlie the biological heterogeneity of HER2 positive tumours and may identify patients suitable for a specific targeted therapy but does not predict patient outcome for those receiving trastuzumab. PLA proved to be a useful tool for detecting, visualising and quantifying the frequency of protein-protein interactions in archival formalin fixed paraffin embedded tissue samples.

Keywords: HER2, PLA, Heterodimer, Breast Cancer, Trastuzumab 


\section{Introduction}

Breast carcinomas are heterogeneous in terms of different histological characteristics and genetic and molecular variations, which control patient prognosis and tumour performance [1,2]. Human Epidermal Growth Factor Receptor (HER)2 (neu or cerbB-2) overexpression is related with higher level of metastasis development and are amongst those with the worst prognosis [3] representing $10 \%-23 \%$ of breast tumours [4-6]. The HER family is composed of four different types: HER1 (EGFR or c-erbB-1), HER2, HER3 (c-erbB-3) and HER4 (c-erbB-4) [5]. These compile the type I group of the Receptor Tyrosine Kinases (RTKs) and regulate several cellular metabolic reactions $[7,8]$. RTKs can function as controllers of cellular progress, however they may influence the development and improvement of different types of carcinoma [9].

All members of the HER family, apart from HER2, are activated by a group of transmembrane precursor protein molecules, which possess a conserved epidermal growth factor (EGF)-like domain [10]. Each HER member has specific ligands that they interact with and this ligand-ectodomain interaction encourages either homo- or hetero-dimerisation [11]. HER2 does not interact with any ligand and therefore its conformation arm is constantly predisposed to exist in a competent form and ready to connect with any of the other monomers from the same family [12], HER2 the being preferred receptor for dimerisation incidence $[13,14]$.

HER2 positive breast cancer patients are submitted to targeted therapies that include trastuzumab (Herceptin ${ }^{\mathrm{TM}}$; Genentech), which disrupts its signalling mechanisms. Only $35 \%$ of patients with HER2 metastatic breast cancer demonstrate a response when submitted to trastuzumab [15]. Nonetheless, when the therapeutic antibody is 
applied with first-line chemotherapy, the levels of success can increase up to $84 \%$ $[16,17]$. Therefore alternative mechanisms that are not disturbed by trastuzumab might be implicated in carcinoma expansion [18]. Trastuzumab might be effective at initial treatments, however after a period of time acquired resistance increases substantially. Our understanding of these resistance mechanisms remain unclear although several have been proposed (reviewed in ref [19]). The semi-quantitative methods for determination of HER2, such as immunohistochemistry (IHC), might not be adequate and/or sufficient to predict high levels of therapy success.

Moreover, the majority of preceding studies on the HER family in breast cancer have paid attention on either individual expression of the receptor monomers or their coexpression, describing the association with the different clinicopathological parameters [20]. In breast cancer, both EGFR and HER2 expression are highly associated with poor outcome characteristics [21-24] and with negative oestrogen receptor (ER) status [21]. The co-expression of two or more receptors indicate an even more unfavourable outcome [23-26]. Accurate quantification of protein expression and other biological characteristics, such as HER heterodimerisation, could be important to elucidate and predict patient outcome, particularly with HER targeted therapies. The action of these molecules is controlled by a complex system that includes structures modifications or connections with other molecules such as ligands; the consequence heterodimer arrangements will trigger different pathways and consequently different outcomes $[27,28]$. Thus, quantification of HER heterodimerisation status might be important to elucidate their roles for detailed biological outcome. Therefore this study was aimed at investigating the coexpression and dimerisation of the HER family in HER2+ breast cancer in order to understand their role in the disease. 


\section{Material and Methods}

\section{Patient samples}

Primary breast cancer series (Unselected Series)

The patient series comprised 1,858 unselected primary operable invasive breast carcinoma cases, presenting between 1986-1998, from the well-characterised Nottingham-Tenovus Primary Breast Carcinoma Series. [29-31]. Amongst all patients, $1,256(67.6 \%)$ were 50 years or over at presentation. A total of $354(19.1 \%)$ tumours were grade I, $616(33.3 \%)$ grade II and $880(47.6 \%)$ grade III. A total of $1,367(73.9 \%)$ of patients had tumours of $1.5 \mathrm{~cm}$ or larger in size. Additionally 1,187 (64.1\%) cases revealed tumour stage N0, 505 (27.3\%) stage N1 and 159 (8.6\%) stage N2.

Biological characterisation, including immunoreactivity, marking and categorising of ER, progesterone receptor (PgR), and Triple Negative Phenotype (TN) were delineated in this series as previously described $[25,26,32,33]$.

HER2+ adjuvant trastuzumab series

The HER2+ adjuvant trastuzumab series consisted of 143 primary operable breast tumours from patients presenting between 2003 and 2010 who received adjuvant trastuzumab. A total of $79(56.4 \%)$ patients were aged over or equal to 50 years, and $61(43.6 \%)$ were less than 50 years old. The age of patients at presentation ranged between $31-79$ years (median and mean of 52 years). At primary diagnosis, 3 
(2.1\%) tumours were grade $1,37(25.9 \%)$ grade 2 , and $103(72.0 \%)$ cases were grade 3 . A total of $120(83.9 \%)$ patients had tumours $1.5 \mathrm{~cm}$ or larger. Relapse occurred in 23 (16.1\%) cases, distant metastasis in 17 (12.1\%) cases, and 10 (7.0\%) patients died from breast cancer. Local recurrence occurred in $7(4.9 \%)$ of cases and regional recurrence in $1(0.8 \%)$ case.

\section{Immunohistochemistry and Chromogenic in situ Hybridisation}

TMAs were prepared as previously described [25]. Immunohistochemistry was performed using Novolink Polymer Detection Systems (Leica). The primary antibodies were used to detect HER2 (Dako, 1:400), EGFR (clone 31G7, Invitrogen, 1:30), HER3 (clone RTJ1, Leica, 1:30), HER4 (Rabbit polyclonal, Thermo Scientific, 1:100), ER (clone SP1, Dako, 1:50) and PgR (clone PgR 636, Dako, 1:125) for 30 minutes incubation. TMA sections were counterstained with Mayer's haematoxylin. Immunoreactivity of HER2 in TMA cores was scored using standard HercepTest guidelines (Dako). Chromogenic in situ Hybridisation (CISH) was used to quantify HER2 gene amplification using the HER2 FISH pharmDx ${ }^{\mathrm{TM}}$ plus HER2 $\mathrm{CISH}$ pharmDx ${ }^{\mathrm{TM}}$ kit (Dako) as previously described [26]. HER2 classification was assessed by using American Society of Clinical Oncology guidelines as previously described [26].

The expression of ER, PgR, HER3, HER4 and EGFR were evaluated by assessing percentage staining [34]. Only invasive cancer cells localised within tissue cores were considered and only cores exhibiting at least $15 \%$ of tumour cells were scored. TMAs were scored using high-resolution digital images (NanoZoomer; Hamamatsu Photonics), at x20 magnification, using a web-based interface (Distiller; Slidepath Ltd).

\section{in situ Proximity Ligation Assay (PLA)}


Quantification of HER heterodimers was measured using in situ PLA for brightfield microscope as per the manufacturer's instructions (Duolink kit, Olink). $4 \mu \mathrm{m}$ TMA sections were mounted on X-traTM adhesive micro slide (Surgipath, Leica).

Deparaffinisation was performed and heat induced antigen retrieval was executed for $20 \mathrm{~min}$ in citrate buffer ( $\mathrm{pH} 6.0)$. Endogenous peroxidase was quenched using $0.3 \%$ hydrogen peroxide for $5 \mathrm{~min}$ and followed by a blocking solution for $30 \mathrm{~min}$ at $37^{\circ} \mathrm{C}$. To detect heterodimers, target antibodies from two different species were applied at previously determined optimal conditions. The anti-HER2 rabbit antibody (Dako, 1:200) was used for all PLA detections. For HER2/HER3 heterodimer detection, antiHER3 mouse antibody (clone 2F12, Neomarkers, 1:40) was used, and incubated with the HER2 antibody for $30 \mathrm{~min}$ at room temperature (RT). For HER2/EGFR heterodimer detection, the anti-EGFR mouse antibody (clone EGFR-R2, Santa Cruz, 1:10) and for HER2/HER4 interaction the anti-HER4 antibody mouse (clone HFR1, Abcam Ltd, 1:50) were used respectively. Both the HER2/EGFR and HER2/HER4 antibodies were incubated for $60 \mathrm{~min}$ at RT. This was followed by incubation with the PLA-probe in a pre-heated humidity chamber for 90 min at $37^{\circ} \mathrm{C}$. Hybridisation/ ligation incubation took place for $30 \mathrm{~min}$ and amplification for $120 \mathrm{~min}$ at $37^{\circ} \mathrm{C}$. To detect hybridisation, Horse Radish Peroxidase was used and incubated for $30 \mathrm{~min}$ at RT followed by appliance of substrate solution for 10 min at RT. Counterstaining was performed using Duolink ${ }^{\circledR}$ nuclear staining for 2 min at RT followed by washing the slides under running tap water for 10 min. Slides were mounted with a coverslip after dehydration of the sections.

\section{Image Analysis}

To quantify the HER heterodimerisation, image analysis was employed using Duolink ${ }^{\circledR}$ ImageTool (Olink, Sweden). High-resolution images of TMA sections were acquired at x40 magnification (NanoZoomer). 
One observer (FFTB) scored all IHC and PLA results, which were rescored arbitrarily revealing a high concordance between both occasions. Furthermore the PLA procedure was performed three times on HER2+ cases $(n=143)$ revealing a good correlation amongst the three experiments (kappa value, 0.735 ).

\section{Statistical analysis}

All statistical analyses were performed using SPSS 19.0 (SPSS Inc., Chicago, Illinois). Pearson's $\chi^{2}$ association analysis was employed in support of inter-relationships between dimerisation occurrence status with clinicopathological parameters, and biomarkers including HER2 gene amplification. For any relationship to be considered significant a p-value of $<0.05$ was used.

\section{Ethics}

Nottingham Research Ethics Committee 2 approved this research project under the title of "Development of a molecular genetics classification of breast cancer".

\section{RESULTS}

\section{HER2 status in the Unselected series}

Regarding HER2 protein expression, 1,604 (86.3\%) of patients in the Unselected series were negative, $74(4.0 \%)$ were $2+$ equivocal faction and $180(9.7 \%)$ were $3+$ positive. HER2 gene amplification was observed in 160 (14.4\%) patients resulting in a total of $224(12.1 \%)$ HER2+ cases.

\section{HER heterodimer frequency in the Unselected series}

The unselected primary breast cancer cases revealed a range of signals/cell for each heterodimer which were predominantly detected on the membrane of tumour cells: HER2/EGFR (0-20.2 signals/cell), HER2/HER3 (0-34.6 signals/cell) and HER2/HER4 
(0-17.2 signals/cell). The cut-off point to define the heterodimer status was determined using X-tile [35] which dichotomised data into low and high levels of heterodimerisation. It was therefore considered that low levels of dimers were in those cases showing less than 1.0 HER2/EGFR signals per cell, less than 4.5 HER2/ HER3 signals per cell and less than 3.4 HER2/HER4 signals per cell (Figure 1A, B and C, respectively). Any incidence above these limits were accepted as positive levels of heterodimerisation (Figure 1D, E and F respectively).

The incidence of HER2/EGFR heterodimers in the Unselected series revealed positive levels of HER2/EGFR heterodimers in 104/812 (12.8\%) cases (Table 1). Similar levels of the HER2/HER3 $(97 / 743,13.1 \%)$ and HER2/HER4 (96/891, 10.8\%) heterodimers were observed. There were significant positive associations between the incidences of all HER heterodimers (Tables $2 A-B$, all $p<0.001$ ).

\section{Association of HER heterodimers and biomarkers expression in the}

\section{Unselected series}

As predicted, there were strong positive correlations between all three HER heterodimers and HER2 status (all $p<0.001$, Table 3A). As a consequence, the heterodimers were associated with poor clinicopathological parameters such as high lymph node stage, tumour grade, NPI and a significantly higher risk of recurrence (Supplementary Table 1). A total of $81 / 96$ (84.4\%) breast cases showing HER2/EGFR heterodimers were HER2+. Of the 15 cases that showed HER2/EGFR dimers but not HER2 over-expression, the majority $(11 / 15,73 \%)$ had very low levels of heterodimers ( $<2.4$ signals/cell). Two cases had HER2 protein expression, regarded as 2+ determined by IHC but did not show gene amplification in $\mathrm{CISH}$. The remaining two cases had high levels of HER2/EGFR dimers but no over-expression of HER2. There were a proportion of HER2+ cases $(27 / 108,25 \%)$ that did not express 
HER2/EGFR heterodimers. In terms of the presence of HER2/HER3 heterodimers, a significant proportion of cases showing HER2/HER3 heterodimers were HER2+ (79/89, 89\%). Of those remaining, $7 / 10$ cases had relatively low levels of heterodimers as detected by PLA ( $<8.9$ signals/cell) and 2/10 cases had increased HER2 protein expression (2+) but showed no gene amplification by CISH. There were a number of HER2+ cases, 33/112 (30\%) that did not show dimerisation of HER2/HER3. A similar observation was made with the HER2/HER4 heterodimers where $76 / 86(88 \%)$ of cases with these heterodimers were HER2+. The majority of remaining cases had low levels of heterodimers ( $6 / 10$ cases; $<4.7$ signals/cell) or showed overexpression of HER2 protein but not amplification of the gene. A total of 62/138 (45\%) HER2+ cases did not show HER2/HER4 heterodimers.

Interestingly, 59/89 (66\%) cases with HER2/EGFR heterodimers did not express EGFR protein $(p=0.002)$. In contrast, the majority of tumours $(71 / 78,91 \%)$ showing HER2/HER3 heterodimers expressed HER3 protein. Likewise, all but 5 cases (6.3\%) that were positive for HER2/HER4 heterodimers were positive for the HER4 protein $(p=0.004)$. All HER heterodimers were significantly correlated with ER and PgR negativity and Triple Negative tumours (Table $3 \mathrm{~A}$, all $\mathrm{p}<0.001$ ).

\section{Association of HER heterodimers and HER2 gene amplification in the Unselected series}

There was significant correlation between HER2 gene amplification with the number of detected signals of A) HER2/EGFR $\left.\left(r^{2}=0.381, p<0.001\right), B\right)$ HER2/HER3 $\left(r^{2}=0.429\right.$, $\mathrm{p}<0.001)$ and $\mathrm{C})$ HER2/HER4 $\left(\mathrm{r}^{2}=0.377, \mathrm{p}<0.001\right)$ as shown in Figures $2 \mathrm{~A}, \mathrm{~B}$ and $\mathrm{C}$ However some cases harbouring HER2 gene amplification did not reveal heterodimerisation of HERs.

\section{HER heterodimer frequency in HER2+ breast cancer}


In HER2+ breast cancer, 168/229 (73.4\%) of cases showed HER2/EGFR heterodimers, 149/226 (65.9\%) had high levels of HER2/HER3 heterodimers and approximately half of the cases $(131 / 243,53.9 \%)$ had HER2/HER4 heterodimers (Table 1). Similar to the Unselected series, the presence of all three heterodimers were significantly associated with each other (Table 3B, $p<0.001$ ). A total of $73 / 142$ (51.4\%) HER2+ tumours expressed all three heterodimers (Table 4) whereas only $32 / 142(22.5 \%)$ cases did not show expression of any of the heterodimers investigated. Expression of only one heterodimer or two heterodimers were less commonly observed.

\section{Association of HER heterodimers and clinicopathological parameters in HER2+ breast cancer}

Correlations between the different HER2 heterodimers and clinicopathological parameters are summarised in Table 5. Both HER2/EGFR and HER2/HER3 heterodimers were associated with high tumour grade $(p=0.006$ and $p=0.017$, respectively). The presence of HER2/EGFR heterodimers was also significantly associated with a poor NPI score $(p=0.048)$. The HER2/HER3 interaction was differentiated from the other HER family interactions by an association with development of distant metastases $(p=0.039)$. Finally, HER2/HER4 dimerisation incidence was not associated with any of the clinicopathological parameters investigated.

\section{Association of HER heterodimers and biomarker expression in HER2+ breast cancer}

Table 3B summarises the association of the different HER family heterodimers against the protein expression of the HER family (EGFR, HER2, HER3 and HER4), as detected by IHC, and the hormone receptors ER and PgR. Similar to that observed in 
the Unselected series, the expression of the HER2/EGFR heterodimer in the HER2+ series was independent of EGFR expression where approximately half of the HER2/ EGFR heterodimer positive cases were negative for EGFR protein. In contrast, only 6/121 (5.0\%) and 2/108 (1.9\%) cases positive for the HER2/HER3 and HER2/HER4 heterodimers showed negative expression of HER3 and HER4 respectively.

There was a significant association of HER2/EGFR, HER2/HER3 and HER2/HER4 heterodimers with negative ER $(p=0.002, P<0.001$ and $p<0.001$, respectively $)$ and PgR status ( $p=0.016, P=0.001$ and $p<0.001$, respectively). HER2/HER3 heterodimers were not associated with either ER or PgR.

HER2/HER3 was the only heterodimerisation not highly correlated with Ki67 expression, the nuclear protein severely correlated with ribosomal RNA transcription and is expressed mostly in proliferative cells $[36,37]$.

\section{HER heterodimers and their association with patient outcome}

High levels of all three HER2 dimers showed a significantly worse outcome for both BCSS (Figures $3 A, C, E$ ) and DFI (Figures 3B,D,F) in the Unselected series. Multivariate Cox regression including tumour size, stage and grade, in the Unselected series demonstrated high levels of HER2 heterodimers were independent predictors for worse BCSS: HER2/EGFR (HR=0.64, 95\% CI=0.45-0.89, $\mathrm{p}=0.009)$, HER2/HER3 $(\mathrm{HR}=0.62,95 \% \mathrm{CI}=0.45-0.62, \mathrm{p}=0.006), \mathrm{HER} 2 / \mathrm{HER} 4 \quad(\mathrm{HR}=0.66,95 \%$ $C I=0.48-0.92, p=0.014)$, and worse DFI: HER2/EGFR $(H R=0.64,95 \% C I=0.47-0.88$, $\mathrm{p}=0.005$,$) HER2/HER3 (\mathrm{HR}=0.72,95 \% \mathrm{CI}=0.53-0.98, \mathrm{p}=0.037), \mathrm{HER} 2 / \mathrm{HER} 4$ $(\mathrm{HR}=0.69,95 \% \mathrm{C}=0.51-0.94, \mathrm{p}=0.017)$. However, the association between HER2 heterodimers with patient outcome was not significant in patients with HER2+ breast cancer only (trastuzumab naïve or trastuzumab treated, data not shown). 


\section{Discussion}

This study has utilised chromogenic PLA as an innovative procedure for in situ exposure of HER2 heterodimers such as EGFR/HER2, HER2/HER3 and HER2/HER4, in a large series of paraffin embedded TMA breast tumours. This technique has demonstrated high levels of specificity, sensitivity and consistency with low levels of background. The quantification analysis demonstrated to be robust and with reproducible results amongst the different dimers here considered.

Previously, IHC has been used as a semi-quantitative approach to detect the existence of distinct proteins being limited to single protein or co-expression recognition. Consequently it is not possible to observe protein-protein interactions using this limited technique. Moreover, co-expression of two proteins, such as the HER family, does not necessarily mean that heterodimerisation will occur, as the process is dependent on interaction with ligands to trigger this reaction. So methods, such as PLA, are a suitable solution to quantify protein interaction and visualise and quantify in situ heterodimerisation of the HER family.

For all three HER heterodimers investigated in breast cancer, it is apparent that whilst HER2 over-expression is the dependent factor in dimerising with the other members of the HER family, the protein expression of EGFR, HER3 and HER4 in HER2+ breast cancer does not necessarily result in heterodimerisation. HER2 has previously been suggested as the dominant monomer for heterodimerisation comparing with any others from the same family [13]. HER2 does not include an ectodomain where a ligand can attach, however it is competent to perform as a coreceptor with an extraordinary affinity to interact with the same family members forming heterodimers [9]. Within RTKs Type I group, HER2 is the most favourable 
molecule to interact with the others due to extend ligand/heterodimer linkage and therefore prolonging MAPK pathway $[5,38,39]$ relating these cases with high biological activity. Additionally HER2 does not interact with any ligand and therefore its conformation arm is constantly predisposed to exist in a competent form and ready to connect with any of the other monomers from the same family [12]. Even though HER2/HER3 dimer has been reported as the most frequent dimer in breast cancer [20], it was found that all three HER heterodimers were expressed at a similar frequency. This might be explained by critical factors of the PLA such as the use of different antibodies, different cut-off points and/or the designation of the overexpression status. The results of brightfield versus fluorescent could also contribute to the evident discrepancies. However both these two techniques produce similar results in both cell culture or tissue samples where chromogenic PLA is as specific and sensitive on quantification analysis as fluorescent PLA [40]. Despite these variances, we similarly showed an association between HER2/HER3 heterodimers and poor prognostic factors including high tumour grade and stage, ER negative tumours and HER2 over-expression/amplification.

Although both EGFR and HER2 protein overexpression are correlated with worse outcome $[22,21]$, HER2/EGFR dimerisation has not been well documented in breast cancer. We show for the first time, that HER2/EGFR heterodimers are highly prevalent in HER2+ breast cancer and are correlated with poor outcome. This is in contrast to a previous study which showed EGFR and HER2 co-expression had no significant association with survival [26].

The number of HER heterodimer signals in tumours showing HER2 over-expression/ amplification revealed a significant association and therefore a directly relation between these two factors, suggesting and confirming the dependency of high levels 
of heterodimerisation and HER2. However some cases did not reveal the presence of any heterodimers even though HER2 gene amplification or protein over-expression was apparent. Some occurrences, such as alternative splicing, modification of the transcription mechanism or even the lack of ligands might be the cause for the absence of the heterodimerisation signals detection in these cases [41].

Within HER2+ breast cancer, it was difficult to discriminate between each of the interactions since such a high association between the three different HER2 heterodimers occurred. However, HER2/HER3 is distinguished from the other heterodimers by being the only interaction with a significant association with high distant metastasis $(p=0.039)$. This is supported by the idea that HER3 is highly associated with the development of metastases [42]. Also HER2/HER3 was the only heterodimerisation not associated with ki67, suggesting that HER2/HER3 promotes high rates of cell proliferation, though not related with Ki67 pathway. EGFR/HER2 heterodimer was correlated with high tumour grade and poor NPI. On the other hand HER2/HER4 was not highly associated with any of the clinicopathological parameters, revealing the least influence in the poor outcome features. Other studies have already revealed HER4 is associated with a better outcome compared with other members of the HER family [24], which is in concordance with our results. However in general, i.e. primary series, heterodimerisation HER2/HER4 was highly associated with all clinicopathological parameters excluding vascular invasion and regional recurrence.

Despite levels of the three HER heterodimers were revealed to be associated with worse DFI and BCSS in breast cancer, we were not able to discriminate divergent outcomes based on HER2 dimerisation levels within the HER2+ population only whether treated by trastuzumab or not. However, the results for the trastuzumab adjuvant series have a limited number of cases and relatively short follow-up. Further 
studies are therefore required to determine the role of HER2 heterodimers in patients receiving trastuzumab.

\section{Conclusions}

We have observed that HER2 heterodimers are significantly correlated with poor outcome features in breast cancer and note that HER2 overexpression encourages heterodimerisation, in order to stimulate growth, malignant development [43] and migration [44], despite of being impossible to interact with any ligand. Furthermore, despite the interaction levels undoubtedly hold beneficial knowledge, it will be fundamental to discriminate the different ligand/receptor interactions and reveal their value on patient outcome. Protein or protein-protein interaction quantification, using PLA, could be used to investigate sub-cellular developments helping to divulge both upstream and downstream pathways in HER2+ breast cancer in order to identify possible targets for therapeutic interventions and avoid development of resistance which occurs in current treatment strategies. However, our results strongly suggest there is no evidence to suggest that the identification of HER2 heterodimers will currently enhance the management of HER2+ patients receiving trastuzmab.

\section{Acknowledgements}

We would like to thank the University of Nottingham for funding the Studentship.

\section{Abbreviations}

HER: Human Epidermal Growth Factor Receptor; RTKs: Receptor Tyrosine Kinases;

EGF: Epidermal Growth Factor; STATs: Signal Transducer and Activation of Transcription; PI3K: Phosphatidylinositol (PtdIns) 3-Kinase; IHC:

Immunohistochemistry; ER: Oestrogen Receptor; NPI: Nottingham Prognostic Index; PgR: Progesterone Receptor; TN: Triple Negative Phenotype; ASCO: American 
Society of Clinical Oncology; CISH: Chromogenic in situ Hybridisation; TMA: Tissue Microarray; PLA: in situ Proximity Ligation Assay; HRP: Horse Radish Peroxidase.

\section{Author's Contributions}

FFTB, CCN and ACD generated, assembled data on protein expression, gene amplification, and heterodimerisation quantification. TAF and PM acquired clinical data. FFTB, ACD, TAF, PM, ARG analysed and interpreted the data. IOE, ARG, EAR and SC conceived the study, participated in its design and subsequent coordination. All the authors participated in the interpretation of data and drafting the manuscript. All authours have read and approved the final manuscript.

\section{Competing interests}

The authors declare that they have no competing interests. 


\section{References}

1. Christina Curtis SPS, Suet-Feung Chin, Gulisa Turashvili, Oscar M. Rueda, Mark J. Dunning, Doug Speed, Andy G. Lynch, Shamith Samarajiwa, Yinyin Yuan, Stefan Gra"f, Gavin Ha, Gholamreza Haffari, Ali Bashashati, Roslin Russell, Steven McKinney, METABRIC Group, Anita Langerød, Andrew Green, Elena Provenzano, Gordon Wishart, Sarah Pinder, Peter Watson, Florian Markowetz, Leigh Murphy, Ian Ellis, Arnie Purushotham, Anne-Lise BørresenDale, James D. Brenton, Simon Tavare, Carlos Caldas \& Samuel Aparicio (2012) The genomic and transcriptomic architecture of 2,000 breast tumours reveals novel subgroups. Nature 486:346-352

2. Tsuda $\mathrm{H}$ (2008) Individualization of breast cancer based on histopathological features and molecular alterations. Breast Cancer 15 (2): 121-132

3. Yu DH, Hung MC (2000) Overexpression of ErbB2 in cancer and ErbB2targeting strategies. Oncogene 19 (53):6115-6121

4. Dennis J. Slamon GMC, Steven G. Wong, Wendy J. Levin, Axel Ullrich, William L. Mcguire (1987) Human Breast Cancer: Correlation of Relapse and Survival with Amplification of the HER-2Ineu Oncogene. Science:177-183 5. Caroline J Witton JRR, James J Going, Timothy G Cooke and John MS Bartlett (2003) Expression of the HER1-4 family of receptor tyrosine kinases in breast cancer. J Pathol 200:290-297.

6. Katri Koninki MT, Anssi Auvinen, Jorma Isola email (2009) HER-2 positive breast cancer: decreasing proportion but stable incidence in Finnish population from 1982 to 2005. Breast Cancer Research 11 (3):R37. 7. Gschwind A, Fischer OM, Ullrich A (2004) The discovery of receptor tyrosine kinases: targets for cancer therapy. Nature Reviews Cancer 4 (5):361-370. 8. Vandergeer $P$, Hunter T, Lindberg RA (1994) Receptor protein-tyrosine kinases and their signal-transduction pathways. Annual Review of Cell Biology 10:251-337

9. Zwick E, Bange J, Ullrich A (2001) Receptor tyrosine kinase signalling as a target for cancer intervention strategies. Endocrine-Related Cancer 8 (3): 161-173

10. Heldin CH (1996) Protein tyrosine kinase receptors. Cancer Surveys 27:7-24

11. Hudis CA (2007) Drug Therapy: Trastuzumab - Mechanism of Action and Use in Clinical Practice. The New England Journal of Medicine 357 (1):39-51 12. Burgess AW, Cho HS, Eigenbrot C, Ferguson KM, Garrett TPJ, Leahy DJ, Lemmon MA, Sliwkowski MX, Ward CW, Yokoyama S (2003) An open-and-shut case? Recent insights into the activation of EGF/ErbB receptors. Molecular Cell 12 (3):541-552

13. Tzahar E, Waterman H, Chen XM, Levkowitz G, Karunagaran D, Lavi S, Ratzkin BJ, Yarden Y (1996) A hierarchical network of interreceptor interactions determines signal transduction by neu differentiation factor/ neuregulin and epidermal growth factor. Molecular and Cellular Biology 16 (10):5276-5287

14. Bartlett JMS, Ibrahim M, Jasani B, Morgan JM, Ellis I, Kay E, Connolly $Y$, Campbell F, O'Grady A, Barnett S, Miller K (2009) External Quality Assurance 
of HER2 FISH and ISH Testing Three Years of the UK National External Quality Assurance Scheme. American Journal of Clinical Pathology 131 (1):106-111. 15. Vogel CL, Cobleigh MA, Tripathy D, John C. Gutheil, Lyndsay N. Harris, Louis Fehrenbacher, Dennis J. Slamon, Maureen Murphy, William F. Novotny, Michael Burchmore, Steven Shak, Stanford J. Stewart, Press M (2002) Efficacy and Safety of Trastuzumab as a Single Agent in First-Line Treatment of HER2-Overexpressing Metastatic Breast Cancer. Journal of Clinical Oncology 20:719-726.

16. Burris H, Yardley D, Jones S, Houston G, Broome C, Thompson D, Greco FA, White M, Hainsworth J (2004) Phase II trial of trastuzumab followed by weekly paclitaxel/carboplatin as first-line treatment for patients with metastatic breast cancer. Journal of Clinical Oncology 22 (9):1621-1629. 17. Slamon DJ, Jones BL, Shak S, Fuchs H, Paton V, Bajamonde A, Fleming T EW, Wolter J, Pegram M, Baselga J, Norton L. (2001) Use of Chemotherapy Plus A Monoclonal Antibody Against Her2 For Metastatic Breast Cancer That Overexpresses Her2. The New England Journal of Medicine 344 (11):783-792 18. Baselga J, Rischin D, Ranson M, H. Calvert, E. Raymond, D.G. Kieback, S.B. Kaye, L. Gianni, A. Harris, T. Bjork, S.D. Averbuch, A. Feyereislova, H. Swaisland, F. Rojo, Albanell J (2002) Phase I Safety, Pharmacokinetic, and Pharmacodynamic Trial of ZD1839, a Selective Oral Epidermal Growth Factor Receptor Tyrosine Kinase Inhibitor, in Patients With Five Selected Solid Tumor Types. Journal of Clinical Oncology 20(21):4292-302.

19. Fabricio F T Barros DGP, Ian O Ellis \& Andrew R Green (2010) Understanding the HER family in breast cancer: interaction with ligands, dimerization and treatments. Histopathology 56:560-572.

20. Melanie Spears KJT, Alison F. Munro, Carrie A. Cunningham, Elizabeth A. Mallon, Chris J. Twelves, David A. Cameron, Jeremy Thomas, John M. S. Bartlett (2011) In situ detection of HER2:HER2 and HER2:HER3 proteinprotein interactions demonstrates prognostic significance in early breast cancer. Breast Cancer Res Treat. 132(2):463-70.

21. Shinichi Tsutsui AK, Shinji Ohno, Shigeru Murakami, Junko Kinoshita, and Yoichi Hachitanda (2002) Prognostic and Predictive Value of Epidermal Growth Factor Receptor in Recurrent Breast Cancer. Clinical Cancer Research 8:34543460

22. Sainsbury JRC, Malcolm AJ, Appleton DR, Farndon JR, Harris AL (1985)

Presence of epidermal growth-factor receptor as an indicator of poor prognosis in patients with breast-cancer Journal of Clinical Pathology 38 (11): $1225-1228$.

23. Toi M, Tominaga T, Osaki A, Toge T (1994) ROLE OF EPIDERMAL GROWTH-FACTOR RECEPTOR EXPRESSION IN PRIMARY BREAST-CANCER RESULTS OF A BIOCHEMICAL-STUDY AND AN IMMUNOCYTOCHEMICAL STUDY. Breast Cancer Research and Treatment 29 (1):51-58.

24. Suo Z, Risberg B, Klasson MG, Willman K, Tierens A, Skovlund E, Nesland JM (2002) EGFR family expression in breast carcinomas. c-erbB-2 and cerbB-4 receptors have different effects on survival J Pathol 196:17-25. 25. Dalia M. Abd El-Rehim GB, Sarah E. Pinder, Emad Rakha, Claire Paish, John F.R. Robertson, Douglas Macmillan, Roger W. Blamey and Ian O. Ellis (2005) High-throughput protein expression analysis using tissue microarray technology of a large well-characterised series identifies biologically distinct 
classes of breast cancer confirming recent cDNA expression analyses. Int J Cancer 11:340-350.

26. Abd El-Rehim DM, Pinder SE, Paish CE, JA Bell, RS Rampaul, Rwblamey J, FR Robertson, Nicholson R, Ellis I (2004) Expression and co-expression of the members of the epidermal growth factor receptor (EGFR) family in invasive breast carcinoma. British Journal of Cancer 91 (Breast Cancer):1532-1542. 27. Margolis BL, Lax I, Kris R, Dombalagian M, Honegger AM, Howk R, Givol $D$, Ullrich A, Schlessinger J (1989) All autophosphorylation sites of epidermal growth factor (EGF) receptor and HER2/neu are located in their carboxylterminal tails. Identification of a novel site in EGF receptor. Journal of Biological Chemistry 264 (18):10667-10671

28. Zhang XW, Gureasko J, Shen K, Cole PA, Kuriyan J (2006) An allosteric mechanism for activation of the kinase domain of epidermal growth factor receptor. Cell 125:1137-1149.

29. Ellis IO, Galea M, Broughton N, Locker A, Blamey RW, Elston CW (1992) Pathological prognostic factors in breast-cancer .2. Histological type relationship with survival in a large study with long-term follow-up. Histopathology 20 (6):479-489 30. Elston CW, Ellis IO (1991) Pathological prognostic factors in breast cancer. I. The value of histological grade in breast cancer: experience from a large study with long-term follow-up. Histopathology 19 (5):403-410 31. Galea MH, Blamey RW, Elston CE, Ellis IO (1992) The Nottingham Prognostic Index in primary breast cancer. Breast Cancer Res Treat 22 (3): 207-219

32. Rakha EA, El-Rehim DA, Paish C, Green AR, Lee AHS, Robertson JF, Blamey RW, Macmillan D, Ellis IO (2006) Basal phenotype identifies a poor prognostic subgroup of breast cancer of clinical importance. European Journal of Cancer 42 (18):3149-3156.

33. Rakha EA, El-Sayed ME, Green AR, Lee AHS, Robertson JF, Ellis IO (2007) Prognostic markers in triple-negative breast cancer. Cancer 109 (1):25-32. 34. Rakha EA, Elsheikh SE, Aleskandarany MA, Habashi HO, Green AR, Powe DG, El-Sayed ME, Benhasouna A, Brunet J-S, Akslen LA, Evans AJ, Blamey R, Reis-Filho JS, Foulkes WD, Ellis IO (2009) Triple-Negative Breast Cancer: Distinguishing between Basal and Nonbasal Subtypes. Clinical Cancer Research 15 (7):2302-2310.

35. Camp RL, Dolled-Filhart M, Rimm DL (2004) X-tile: A new bio-informatics tool for biomarker assessment and outcome-based cut-point optimization.

Clinical Cancer Research 10 (21):7252-7259

36. de Azambuja E, Cardoso F, de Castro G, Colozza M, Mano MS, Durbecq V, Sotiriou C, Larsimont D, Piccart-Gebhart MJ, Paesmans M (2007) Ki-67 as prognostic marker in early breast cancer: a meta-analysis of published studies involving 12155 patients. British Journal of Cancer 96 (10):1504-1513. 37. Gerdes J, Schwab U, Lemke H, Stein H (1983) Production of a mouse monoclonal-antibody reactive with a human nuclear antigen associated with cell-proliferation. International Journal of Cancer 31 (1):13-20.

38. Diana Graus-Porta RRB, John M.Daly and Nancy E.Hynes (1997) ErbB-2, the preferred heterodimerization partner of all ErbB receptors, is a mediator of lateral signaling. The EMBO Journal 16 (7):1647-1655 
39. Prenzel N, Fischer OM, Streit S, Hart S, Ullrich A (2001) The epidermal growth factor receptor family as a central element for cellular signal transduction and diversification. Endocrine-Related Cancer 8 (1):11-31 40. Zieba A, Wahlby C, Hjelm F, Jordan L, Berg J, Landegren U, Pardali K (2010) Bright-Field Microscopy Visualization of Proteins and Protein Complexes by In Situ Proximity Ligation with Peroxidase Detection. Clinical Chemistry 56 (1):99-110.

41. Soderberg O, Leuchowius K-J, Kamali-Moghaddam M, Jarvius M, Gustafsdottir S, Schallmeiner E, Gullberg M, Jarvius J, Landegren U (2007) Proximity ligation: a specific and versatile tool for the proteomic era. Genetic engineering 28:85-93.

42. Smirnova T, Zhou ZN, Flinn RJ, Wyckoff J, Boimel PJ, Pozzuto M, Coniglio SJ, Backer JM, Bresnick AR, Condeelis JS, Hynes NE, Segall JE (2012) Phosphoinositide 3-kinase signaling is critical for ErbB3-driven breast cancer cell motility and metastasis. Oncogene 31 (6):706-715.

43. Brennan PJ, Kumogai T, Berezov A, Murali R, Greene MI (2000) HER2/

Neu: mechanisms of dimerization/oligomerization. Oncogene 19 (53): 6093-6101

44. Verbeek BS, Adriaansen-Slot SS, Vroom TM, Beckers T, Rijksen G (1998) Overexpression of EGFR and c-erbB2 causes enhanced cell migration in human breast cancer cells and NIH3T3 fibroblasts. Febs Letters 425 (1): 145-150. 


\section{Figure Legends}

Figure 1. in situ Proximity Ligation Assay dimerisation detection in breast carcinomas showing: negative/low levels of (A) HER2/EGFR, (B) HER2/HER3, (C) HER2/HER4 and positive levels of (D) HER2/EGFR, (E) HER2/HER3 and (F) HER2/HER4

Figure 2. Linear regression analysis between HER family heterodimerisations A) HER2/EGFR, B) HER2/HER3 and C) HER2/HER4 and HER2 gene amplification in the Unselected series. There was a positive correlation between HER2 gene amplification and the number of heterodimers signals

Figure 3. Patient outcome according to HER2 dimer status in the Unselected series of breast cancer. (A) HER2/EGFR - BCSS, (B) HER2/EGFR - DFI, (C) HER2/HER3 - BCSS, (D) HER2/HER3, (E) HER2/HER4 - BCSS, (F) HER2/HER4 DFI 

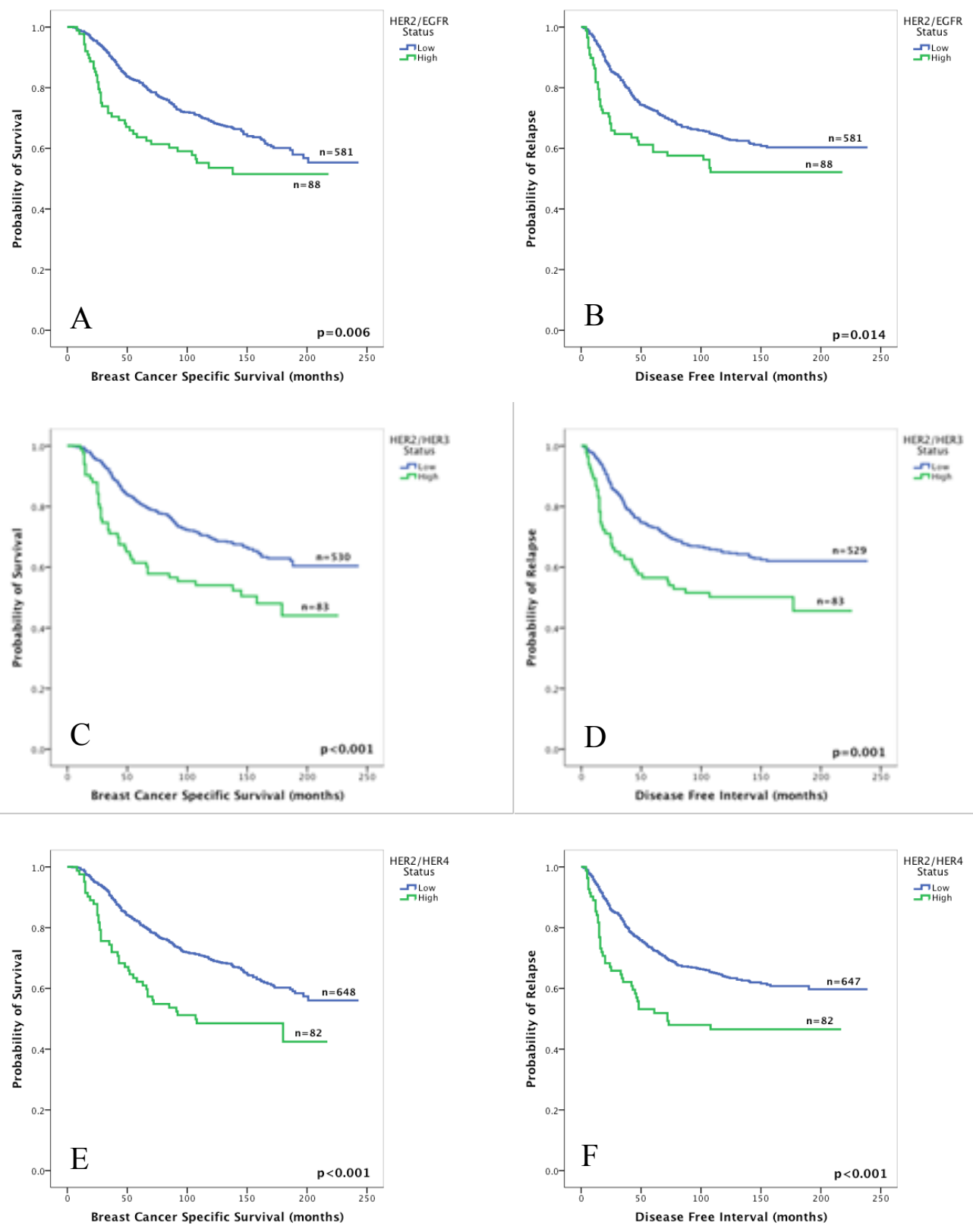

Figure 3 
Table 1. Frequency of HER heterodimers in unselected and HER2+ breast tumours

\begin{tabular}{|c|c|c|c|c|c|c|}
\hline \multirow[t]{2}{*}{ Heterodimer } & \multicolumn{3}{|c|}{ Unselected } & \multicolumn{3}{|c|}{ HER2+ } \\
\hline & Low (\%) & High (\%) & Total & Low $(\%)$ & High (\%) & Total \\
\hline HER2/EGFR & $708(87.2)$ & $\begin{array}{c}104 \\
(12.8)\end{array}$ & $\begin{array}{l}812 \\
(100)\end{array}$ & $\begin{array}{c}61 \\
(26.6)\end{array}$ & $\begin{array}{c}168 \\
(73.4)\end{array}$ & $\begin{array}{l}229 \\
(100)\end{array}$ \\
\hline HER2/HER3 & 646 & $\begin{array}{c}97 \\
(13.1)\end{array}$ & $\begin{array}{l}743 \\
(100)\end{array}$ & $\begin{array}{c}77 \\
(34.1)\end{array}$ & $\begin{array}{r}149 \\
(65.9)\end{array}$ & $\begin{array}{l}226 \\
(100)\end{array}$ \\
\hline HER2/HER4 & $795(89.2)$ & $\begin{array}{c}96 \\
(10.8)\end{array}$ & $\begin{array}{l}891 \\
(100)\end{array}$ & $\begin{array}{c}112 \\
(46.1)\end{array}$ & $\begin{array}{c}131 \\
(53.9)\end{array}$ & $\begin{array}{l}243 \\
(100)\end{array}$ \\
\hline
\end{tabular}


Table 2A. Association between HER heterodimers in Unselected breast cancer series

\begin{tabular}{|c|c|c|c|c|c|c|}
\hline \multirow[b]{2}{*}{ Variable } & \multicolumn{3}{|c|}{ HER2/EGFR } & \multicolumn{3}{|c|}{ HER2/HER3 } \\
\hline & Low (\%) & High (\%) & $\underset{\text { (Chi-Square) }}{\mathrm{p} \text { Value }}$ & Low $(\%)$ & High $(\%)$ & $\underset{\text { (Chi-Square) }}{\mathrm{p} \text { Value }}$ \\
\hline \multicolumn{7}{|c|}{ HER2/ } \\
\hline $\begin{array}{l}\text { I nw } \\
\text { Hioh }\end{array}$ & $\begin{array}{c}387 \text { (97 5) } \\
10 \text { (5) }\end{array}$ & $\begin{array}{l}11(167) \\
55(832)\end{array}$ & $\begin{array}{l}<0.001 \\
(306.265)\end{array}$ & & & \\
\hline
\end{tabular}




\section{HER2/HER4}

\begin{tabular}{|c|c|c|c|c|c|c|}
\hline I nix & 427 roe & 24 & $\begin{array}{l}<0.001 \\
(274.489)\end{array}$ & $36162 ?$ & $45(28)$ & $\begin{array}{l}<0.001 \\
(187.288)\end{array}$ \\
\hline
\end{tabular}

Table 2B. Association between HER heterodimers in HER2+ breast cancer

\begin{tabular}{|c|c|c|c|c|c|c|}
\hline \multirow[b]{2}{*}{ Variable } & \multicolumn{3}{|c|}{ HER2/EGFR } & \multicolumn{3}{|c|}{ HER2/HER3 } \\
\hline & Low (\%) & High (\%) & $\underset{\text { (Chi- Square) }}{\mathrm{p} \text { Value }}$ & Low (\%) & High (\%) & $\underset{\text { (Chi-Square) }}{\mathrm{p} \text { Value }}$ \\
\hline
\end{tabular}

\section{HER2/HER3}

$\begin{array}{lccc}\text { Low } & 38(84.4) & 18(13.7) & <0.001 \\ \text { High } & 7(15.6) & 113(86.3) & (77.182)\end{array}$

\section{HER2/HER4}

$\begin{array}{lcccccc}\text { Low } & 41(95.3) & 36(26.3) & <0.001 & 46(74.2) & 38(32.2) & <0.001 \\ \text { High } & 2(4.7) & 101(73.7) & & 16(25.7) & 80(67.8) & \end{array}$


Table 3A. Relation of HER heterodimers with biomarkers in unselected breast cancer series

\begin{tabular}{|c|c|c|c|c|c|c|c|c|c|}
\hline \multirow[b]{2}{*}{ Variable } & \multicolumn{3}{|c|}{ EGFR/HER2 } & \multicolumn{3}{|c|}{ HER2/HER3 } & \multicolumn{3}{|c|}{ HER2/HER4 } \\
\hline & Low (\%) & High (\%) & $\underset{\text { (Chi- Square) }}{\mathrm{p} \text { Value }}$ & Low (\%) & High (\%) & $\underset{\text { (Chi-Square) }}{\mathrm{p} \text { Value }}$ & Low (\%) & High (\%) & $\underset{\text { (Chi- Square) }}{\mathrm{p} \text { Value }}$ \\
\hline \multicolumn{10}{|l|}{ ER } \\
\hline $\begin{array}{l}\text { Negative } \\
\text { Positive }\end{array}$ & $\begin{array}{l}197(29.4) \\
474(70.6)\end{array}$ & $\begin{array}{l}64(66.0) \\
33(34.0)\end{array}$ & $\begin{array}{l}<0.001 \\
(50.658)\end{array}$ & $\begin{array}{l}169(28.3) \\
429(71.7)\end{array}$ & $\begin{array}{l}56(60.2) \\
37(39.8)\end{array}$ & $\begin{array}{l}<0.001 \\
(37.424)\end{array}$ & $\begin{array}{l}234(30.9) \\
523(69.1)\end{array}$ & $\begin{array}{l}57(64.8) \\
31(35.2)\end{array}$ & $\begin{array}{r}<0.001 \\
(40.035)\end{array}$ \\
\hline \multicolumn{10}{|l|}{ PgR } \\
\hline $\begin{array}{l}\text { Negative } \\
\text { Positive }\end{array}$ & $\begin{array}{l}296(44.6) \\
367(55.4)\end{array}$ & $\begin{array}{l}72(75.8) \\
23(24.2)\end{array}$ & $\begin{array}{l}<0.001 \\
(32.266)\end{array}$ & $\begin{array}{l}264(44.2) \\
333(55.8)\end{array}$ & $\begin{array}{l}65(70.7) \\
27(29.3)\end{array}$ & $\begin{array}{l}<0.001 \\
(22.321)\end{array}$ & $\begin{array}{l}335(44.5) \\
418\end{array}$ & $\begin{array}{l}66(75.9) \\
21\end{array}$ & $\begin{array}{l}<0.001 \\
(30.769)\end{array}$ \\
\hline \multicolumn{10}{|l|}{ EGFR } \\
\hline Negative & $476(80.7)$ & $59(66.3)$ & \multirow[b]{2}{*}{$0.002(9.578)$} & $430(79.2)$ & $60(74.1)$ & \multirow[b]{2}{*}{$0.296(1.094)$} & 527 (78.5) & $57(69.5)$ & \multirow[b]{2}{*}{0.064} \\
\hline Positive & $114(19.3)$ & $30(33.7)$ & & $113(20.8)$ & $21(25.9)$ & & $144(21.5)$ & $25(30.5)$ & \\
\hline \multicolumn{10}{|l|}{ HER2 } \\
\hline $\begin{array}{l}\text { Negative } \\
\text { Positive }\end{array}$ & $\begin{array}{l}655(96.0) \\
27(4.0)\end{array}$ & $\begin{array}{l}15(15.6) \\
81(84.4)\end{array}$ & $\begin{array}{l}<0.001 \\
(455.221)\end{array}$ & $\begin{array}{c}599(94.8) \\
33(5.2)\end{array}$ & $\begin{array}{l}10(11.2) \\
79(88.8)\end{array}$ & $\begin{array}{l}<0.001 \\
(414.975)\end{array}$ & $\begin{array}{c}709(92.0) \\
62(8.0)\end{array}$ & $\begin{array}{l}10(11.6) \\
76(88.4)\end{array}$ & $\begin{array}{l}<0.001 \\
(369.562)\end{array}$ \\
\hline \multicolumn{10}{|l|}{ HER3 } \\
\hline $\begin{array}{l}\text { Negative } \\
\text { Positive }\end{array}$ & $\begin{array}{c}48(8.5) \\
519(91.5)\end{array}$ & $\begin{array}{c}3(3.6) \\
81(96.4)\end{array}$ & $\begin{array}{l}<0.119 \\
(2.427)\end{array}$ & $\begin{array}{c}47(9.0) \\
477(91.0)\end{array}$ & $\begin{array}{c}7(9.0) \\
71(91.0)\end{array}$ & $0.999_{(0.0)}$ & $\begin{array}{c}74(11.7) \\
560(88.3)\end{array}$ & $\begin{array}{c}1(1.3) \\
75(98.7)\end{array}$ & $0.006(7.704)$ \\
\hline \multicolumn{10}{|l|}{ HER4 } \\
\hline Negative & $97(17.1)$ & $6(7.0)$ & \multirow[b]{2}{*}{0.017 (5.743) } & $82(15.4)$ & $5(6.8)$ & \multirow[b]{2}{*}{$0.048(3.919)$} & $125(19.5)$ & $5(6.3)$ & \multirow[b]{2}{*}{$0.004(8.219)$} \\
\hline Positive & $471(82.9)$ & $80(93.0)$ & & 452 (84.6) & 69 (93.2) & & $517(80.5)$ & 74 (93.7) & \\
\hline \multicolumn{10}{|l|}{$\mathbf{T N}$} \\
\hline $\begin{array}{l}\text { No } \\
\text { Yes }\end{array}$ & $\begin{array}{c}20(10.6) \\
168(89.4)\end{array}$ & $\begin{array}{l}20(80) \\
5(20)\end{array}$ & $\begin{array}{l}<0.001 \\
(69.600)\end{array}$ & $\begin{array}{c}14(8.6) \\
148(91.4)\end{array}$ & $\begin{array}{c}22(100) \\
0(0)\end{array}$ & $\begin{array}{l}<0.001 \\
(102.727)\end{array}$ & $\begin{array}{c}30(14.0) \\
185(86.0)\end{array}$ & $\begin{array}{c}18(94.7) \\
1(5.3)\end{array}$ & $\begin{array}{l}<0.001 \\
(69.871)\end{array}$ \\
\hline \multicolumn{10}{|l|}{ Ki67 } \\
\hline Low & $173(30.6)$ & $12(14.1)$ & & $172(33.8)$ & $21(25.3)$ & & $197(31.7)$ & $12(15.4)$ & \\
\hline Moderate & $209(37.0)$ & $34(40.0)$ & $\begin{array}{l}0.004 \\
(11.186)\end{array}$ & 176 & $25(30.1)$ & $0.062(5.573)$ & $211(34.0)$ & 27 & $0.004(10.933$ \\
\hline High & 183 (32.4) & $39(45.9)$ & & 161 & $37(44.6)$ & & 213 & $39(50.0)$ & \\
\hline
\end{tabular}


Table 3B. Relation of HER heterodimers with biomarkers in HER2+ breast cancer

\begin{tabular}{|c|c|c|c|c|c|c|c|c|c|}
\hline \multirow[b]{2}{*}{ Variable } & \multicolumn{3}{|c|}{ EGFR/HER2 } & \multicolumn{3}{|c|}{ HER2/HER3 } & \multicolumn{3}{|c|}{ HER2/HER4 } \\
\hline & Low (\%) & High (\%) & $\underset{\text { (Chi-Square) }}{\mathrm{p} \text { Value }}$ & Low $(\%)$ & High (\%) & $\underset{\text { (Chi- Square) }}{\mathrm{p} \text { Value }}$ & Low (\%) & High (\%) & $\underset{\text { (Chi- Square) }}{\mathrm{p} \text { Value }}$ \\
\hline \multicolumn{10}{|l|}{ ER } \\
\hline Negative & $23(39.7)$ & $102(63.4)$ & \multirow{2}{*}{$\begin{array}{l}0.002 \\
(9.775)\end{array}$} & $23(31.1)$ & $91(62.8)$ & \multirow{2}{*}{$\begin{array}{l}<0.001 \\
(19.699)\end{array}$} & $47(42.7)$ & $81(65.9)$ & \multirow{2}{*}{$\begin{array}{l}<0.001 \\
(12.545)\end{array}$} \\
\hline Positive & $35(60.3)$ & $59(36.6)$ & & $51(68.9)$ & $54(37.2)$ & & $63(57.3)$ & $42(34.1)$ & \\
\hline \multicolumn{10}{|l|}{ PgR } \\
\hline Negative & $32(54.2)$ & 111 (71.6) & \multirow{2}{*}{$\begin{array}{l}0.016 \\
(5.819)\end{array}$} & $36(48.6)$ & 100 (71.4) & \multirow{2}{*}{$\begin{array}{l}0.001 \\
(10.845)\end{array}$} & $62(56.9)$ & $92(76.7)$ & \multirow{2}{*}{$\begin{array}{c}0.001 \\
(10.153)\end{array}$} \\
\hline Positive & $27(45.8)$ & $44(28.4)$ & & $38(51.4)$ & $40(28.6)$ & & $47(43.1)$ & 28 & \\
\hline \multicolumn{10}{|l|}{ EGFR } \\
\hline Negative & $31(59.6)$ & $81(53.6)$ & \multirow{2}{*}{$\begin{array}{l}0.455 \\
(0.558)\end{array}$} & $45(66.2)$ & $73(55.3)$ & \multirow{2}{*}{$\begin{array}{l}0.139 \\
(2.194)\end{array}$} & $64(66.0)$ & $64(54.7)$ & \multirow{2}{*}{0.094} \\
\hline Positive & $21(40.4)$ & $70(46.4)$ & & $23(33.8)$ & $59(44.7)$ & & $33(34.0)$ & $53(45.3)$ & \\
\hline \multicolumn{10}{|l|}{ HER3 } \\
\hline Negative & $4(8.3)$ & $5(3.6)$ & \multirow{2}{*}{$\begin{array}{l}0.190 \\
(1.716)\end{array}$} & $5(7.6)$ & $6(4.9)$ & \multirow{2}{*}{$\begin{array}{l}0.450 \\
(0.570)\end{array}$} & $6(6.8)$ & $2(1.9)$ & \multirow{2}{*}{$0.080(3.055)$} \\
\hline Positive & $44(91.7)$ & $133(96.4)$ & & $61(92.4)$ & $117(95.1)$ & & $82(93.2)$ & $106(98.1)$ & \\
\hline \multicolumn{10}{|l|}{ HER4 } \\
\hline Negative & $0(0.0)$ & $5(3.6)$ & \multirow{2}{*}{$\begin{array}{l}0.184 \\
(1.763)\end{array}$} & $1(1.8)$ & $3(2.1)$ & \multirow{2}{*}{$\begin{array}{l}0.618 \\
(0.249)\end{array}$} & $3(3.5)$ & $4(3.7)$ & \multirow{2}{*}{$0.936(0.006)$} \\
\hline Positive & $47(100.0)$ & $132(96.4)$ & & $68(98.2)$ & $118(97.5)$ & & $83(96.5)$ & $104(96.3)$ & \\
\hline \multicolumn{10}{|l|}{ Ki67 } \\
\hline Low & $2(11.1)$ & $7(10.6)$ & & $4(19.0)$ & $14(21.2)$ & & 7 (15.9) & $9(14.3)$ & \\
\hline Moderate & $11(61.1)$ & $26(39.4)$ & $\begin{array}{l}0.216 \\
(3.062)\end{array}$ & $10(47.6)$ & $21(31.8)$ & $\begin{array}{l}0.400 \\
(1.831)\end{array}$ & $21(47.7)$ & $23(36.5)$ & $\begin{array}{l}0.404 \\
(1.811)\end{array}$ \\
\hline High & $5(27.8)$ & $33(50.0)$ & & $7(33.4)$ & $31(47.0)$ & & $16(36.4)$ & 31 (49.2) & \\
\hline
\end{tabular}


Table 4. Frequency of HER heterodimers in HER2+ breast cancer

\begin{tabular}{cccc}
\hline HER2/EGFR & HER2/HER3 & HER2/HER4 & Frequency \\
+ & - & - & 4 \\
- & + & - & 4 \\
- & - & + & 0 \\
+ & + & - & 24 \\
+ & - & + & 11 \\
- & + & + & 1 \\
+ & + & + & 73 \\
- & - & - & 32 \\
\hline
\end{tabular}


Table 5. Relation of HER heterodimers with clinicopathological features in the HER2+ breast cancer series

\begin{tabular}{|c|c|c|c|c|c|c|c|c|c|}
\hline \multirow[b]{2}{*}{ Variable } & \multicolumn{3}{|c|}{ EGFR/HER2 } & \multicolumn{3}{|c|}{ HER2/HER3 } & \multicolumn{3}{|c|}{ HER2/HER4 } \\
\hline & Low (\%) & High (\%) & $\mathrm{p}$ Value & Low (\%) & High (\%) & $\mathrm{p}$ Value & Low (\%) & High (\%) & $\mathrm{p}$ Value \\
\hline \multicolumn{10}{|l|}{$\begin{array}{l}\text { Lymph Node } \\
\text { Stage }\end{array}$} \\
\hline 1 & $23(39.0)$ & $70(41.7)$ & & 35 & $66(44.3)$ & & $52(47.3)$ & $60(45.8)$ & \\
\hline 2 & $23(39.0)$ & $64(38.1)$ & $\begin{array}{l}0.926 \\
(0.154)\end{array}$ & $29(38.7)$ & $49(32.9)$ & $\begin{array}{l}0.334 \\
(2.191)\end{array}$ & $36(32.7)$ & $47(35.9)$ & $\begin{array}{l}0.866 \\
(0.289)\end{array}$ \\
\hline 3 & $13(22.0)$ & $34(20.2)$ & & $11(14.7)$ & $34(22.8)$ & & $22(20.0)$ & $24(18.3)$ & \\
\hline \multicolumn{10}{|l|}{ Tumour Size } \\
\hline$<1.5 \mathrm{~cm}$ & 10 & $26(15.5)$ & 0.866 & $10(13.0)$ & $24(16.1)$ & 0.534 & $17(15.2)$ & $21(16.0)$ & 0.855 \\
\hline$\geq 1.5 \mathrm{~cm}$ & $51(83.6)$ & $142(84.5)$ & $(0.028)$ & $67(87.0)$ & $125(83.9)$ & $(0.387)$ & $95(84.8)$ & $110(84.0)$ & $(0.033)$ \\
\hline \multicolumn{10}{|c|}{ Tumour Grade } \\
\hline I & $1(1.6)$ & $6(3.6)$ & & $1(1.3)$ & $6(4.0)$ & & $0(0.0)$ & $4(3.1)$ & \\
\hline II & $20(32.8)$ & $25(14.9)$ & $\begin{array}{r}0.006 \\
(9.3267)\end{array}$ & $21(27.3)$ & $19(12.8)$ & $\begin{array}{l}0.017 \\
(8.159)\end{array}$ & $22(19.6)$ & $17(13.0)$ & $\begin{array}{l}0.075 \\
(5.187)\end{array}$ \\
\hline III & $40(65.6)$ & $137(81.5)$ & & $55(71.4)$ & 124 & & $90(80.4)$ & $110(84.0)$ & \\
\hline \multicolumn{10}{|l|}{ Tubule } \\
\hline 1 & $0(0.0)$ & $2(1.2)$ & & $0_{(0.0)}$ & $1(0.7)$ & & $0(0.0)$ & $2(1.6)$ & \\
\hline 2 & $14(23.3)$ & $26(15.9)$ & $\begin{array}{l}0.314 \\
(2.230)\end{array}$ & $16(21.3)$ & $23(15.6)$ & $\begin{array}{l}0.455 \\
(1.576)\end{array}$ & $21(19.1)$ & $17(13.2)$ & $\begin{array}{l}0.207 \\
(3.147)\end{array}$ \\
\hline 3 & $46(76.7)$ & $136(82.9)$ & & $59(78.7)$ & $123(83.7)$ & & $89(80.9)$ & $111(85.3)$ & \\
\hline \multicolumn{10}{|c|}{ Pleomorphism } \\
\hline 1 & $0_{(0.0)}$ & $0(0.0)$ & & $0(0.0)$ & $0(0.0)$ & & $0(0.0)$ & $0_{(0.0)}$ & \\
\hline 2 & $10(16.7)$ & $15(9.1)$ & $\begin{array}{l}0.113 \\
(2.506)\end{array}$ & $11(14.7)$ & $12(8.2)$ & $\begin{array}{l}0.137 \\
(2.209)\end{array}$ & $12(12.0)$ & $9(7.0)$ & $\begin{array}{l}0.265 \\
(1.244)\end{array}$ \\
\hline 3 & $50(83.3)$ & $149(90.1)$ & & $64(85.3)$ & $134(91.8)$ & & $96(88.9)$ & $120(93.0)$ & \\
\hline \multicolumn{10}{|l|}{ Distant } \\
\hline No & $47(78.3)$ & $118(70.7)$ & 0.252 & $61(79.2)$ & $97(66.0)$ & 0.039 & $81(72.3)$ & $86(66.7)$ & 0.343 \\
\hline Yes & $13(21.7)$ & $49(29.3)$ & $(1.310)$ & $16(20.8)$ & $50(34.0)$ & $(4.259)$ & $31(27.7)$ & 43 (33.3) & $(0.901)$ \\
\hline \multicolumn{10}{|l|}{$\begin{array}{l}\text { Mitotic } \\
\text { Frammenev }\end{array}$} \\
\hline 1 & $11(28.3)$ & $23(14.5)$ & & $13(17.3)$ & $21(14.3)$ & & $10(9.1)$ & $18(14.0)$ & \\
\hline 2 & $18(23.3)$ & $42(26.1)$ & $\begin{array}{l}0.490 \\
(1.426)\end{array}$ & $22(29.3)$ & $33(22.4)$ & $\begin{array}{l}0.355 \\
(2.069)\end{array}$ & $31(28.2)$ & $27(20.9)$ & $\begin{array}{l}0.281 \\
(2.538)\end{array}$ \\
\hline
\end{tabular}



Vascular
Invasian

No

Yes

26 (43.3)

90 (54.2)

76 (45.8)

0.744
$(0.1076)$

$36(47$

40 (52.6)

81 (54.7)

67 (45.3)

0.296

58 (54.5)

73 (56.3)

53 (45.5)

56 (43.4)

NPI

Good

Moderate

15 (24.6) $21(12.5)$

37 (60.7)

21 (12.5)

9 (14.7)

52 (30.9)

0.048

$12(15$

(15.6) $\quad 17(11.5)$

$51(66.3)$

$84(56.4)$

14 (18.2)

48 (32.2)

0.200
$(7.295)$

$14(12.5)$

Poor

Death

No

47 (79.7)

$12(20.3)$

114 (72.2)

0.261

Yes

44 (27.8)

(1.265)

58 (79.

97 (69.8)

$15(20.5) \quad 42(30.2)$

0.131

(2.276)

78 (73.6)

28 (26.4)

$81(67.5)$

39 (32.5)

0.318

Local

Recurrence

No

Yes

$\begin{array}{lll}49(80.3) & 117(70.1) & 0.123 \\ & & \end{array}$

$59(76$

$100(67.6)$

18 (23.4) $\quad 48(32.4)$

0.157
$(2.004)$

83 (74.8)

28 (25.2)

$85(65.4)$

45 (34.6)

0.501

(0.453)

Regional

Recurrence

No

$\begin{array}{lll}55 \text { (93.2) } & 140(90.9) & 0.587 \\ & & (0.295)\end{array}$

$71(95.9)$

$127(91.4)$

0.214
$(1.547)$

103 (94.5)

$\begin{array}{ll}111(91.7) & 0.411 \\ 10(8.3) & (0.675)\end{array}$

\begin{tabular}{llllllllll} 
Yes & $4(6.8)$ & $14(9.1)$ & $(0.295)$ & $3(4.1)$ & $12(8.6)$ & $(1.547)$ & $4(5.5)$ & $10(8.3)$ & $(0.675)$ \\
\hline
\end{tabular}


